\title{
PENGARUH KEDISIPLINAN TERHADAP KESULITAN BELAJAR SISWA PENDIDIKAN DASAR
}

\author{
TUSRIYANI \\ Universitas Nusantara Kediri \\ tusriyaniabbas@gmail.com
}

\begin{abstract}
Abstrak
Penelitian ini menggunakan pendekatan kuantitatif dengan populasi penelitian para siswa kelas V SD Negeri Kalimook I sejumlah 378 siswa. Dari populasi tersebut diambil sampel sebanyak 56 siswa dengan menggunakan teknik random sampling secara proporsional (melalui cara undian/acak). Metode pengumpulan data yang digunakan adalah instrumen berupa kuesioner kedisiplinan dan kesulitan belajar. Kuesioner sebelum digunakan untuk mengumpulkan data-data penelitian, terlebih dulu dilakukan pretest untuk melakukan uji reliabilitas dan validitasnya. Data-data penelitian selanjutnya dianalisis dengan menggunakan teknik analisis statistika $r$ korelasi product moment. Diperoleh angka koefisien korelasi sebesar $r_{\text {hitung }}=0,714$. Angka koefisien tersebut lebih besar daripada $r_{\text {tabel }}=0,266$ baik pada taraf signifikan $95 \%$. Jadi $r=0,714>0,266$ yang berarti signifikan.

Berdasarkan hasil analisis tersebut, disimpulkan bahwa terdapat hubungan positif yang signifikan antara kedisiplinan dan kesulitan belajar siswa kelas V SD Negeri Kalimook I.
\end{abstract}

Kata Kunci: Kedisiplinan, Kesulitan Belajar Siswa.

\section{Abstract}

This study uses a quantitative approach with a research population of class V students of SD Negeri Kalimook I totaling 378 students. From the population, a sample of 56 students was taken using proportional random sampling technique (via lottery / random method). Data collection methods used were instruments in the form of disciplinary questionnaires and learning difficulties. Before the questionnaire was used to collect research data, a pretest was first conducted to test the reliability and validity.

The research data were further analyzed using statistical product moment correlation analysis techniques. Obtained correlation coefficient number of $r$ count $=0.714$. The coefficient number is greater than $\mathrm{r}$ table $=0.266$ both at a significant level of $95 \%$. So $r=0.714>0.266$ which means significant.

Based on the results of the analysis, it was concluded that there was a significant positive relationship between discipline and learning difficulties of fifth grade students of SD Negeri Kalimook I

Keywords: Discipline, Student Learning Difficulties. 


\section{Tusiyari}

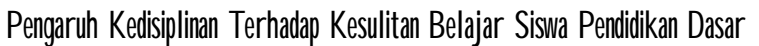

\section{PENDAHULUAN}

Suatu bangsa akan tercermin bila kedisiplinannya terwujud dengan baik dan melalui pendidikanlah sebagai suatu kegiatan pembinaan sikap dan mental yang akan menentukan tingkah laku seseorang. Oleh karena itu untuk melestarikan bentuk tingkah laku tersebut seorang pendidik harus mempertahankannya dengan salah satu alat pendidikan yaitu kedisiplinan.

Dunia pendidikan dewasa ini menghadapi berbagai masalah yang amat kompleks yang memerlukan perhatian kita semua. Salah satu masalah itu adalah kurang disiplin terhadap waktu juga terhadap belajarnya dan tidak mengindahkan peraturan. Masalah tersebut apabila tidak segera diatasi akan semakin mengancam kehidupan generasi bangsa kita khususnya, dan tata kehidupan sosial masyarakat pada umumnya.

Mengingat Undang-Undang RI, Nomor 20 Tahun 2003 tentang Sistem Pendidikan Nasional, dalam tujuan pendidikan, mengamanatkan agar Pendidikan Nasional berfungsi mengembangkan kemampuan dan membentuk watak serta peradaban bangsa yang bermartabat dalam rangka mencerdaskan kehidupan bangsa, bertujuan untuk berkembangnya potensi peserta didik agar menjadi manusia yang beriman dan bertakwa kepada Tuhan YME, berakhlak mulia, sehat berilmu, cakap, kreatif, mandiri, dan menjadi warga negara yang demokratis serta bertanggung jawab.

Menurut Ki Hadjar Dewantara dan Tamansisiwa Pendidikan merupakan usaha kebudayaan yang bermaksud memberi bimbingan dalam hidup dan tumbuh kembangnya jiwa raga anak didik, agar dalam menjalani garis kodrat pribadinya serta menghadapi pengaruh lingkungannya mendapat kemajuan hidup lahir batin. Dalam rangka membangun manusia Indonesia yang seutuhnya pembangunan di bidang pendidikan merupakan sarana dan wahana yang sangat baik untuk pembinaan sumber daya manusia. Oleh karena itu bidang pendidikan perlu mendapat perhatian dan penanganan serta prioritas secara intensif oleh pemerintah dan pengelola pendidikan khususnya.

Pendidikan yang selama ini kita terapkan masih bertumpu pada pendidikan yang berorientasi kenegaraan. Pendidikan yang memiliki obsesi menjadikan bangsa sebagai bangsa yang terhormat dalam bidang pendidikan di tengah kompetisi anakanak pandai di dunia. Yang karenanya, hanya kemampuan akademik yang didorong habis-habisan pengembangannya, sementara pengembangan kejiwaan siswa tidak diperhatikan dengan baik. Oleh karena itulah bimbingan dan konseling sangatlah penting keberadaannya di ruang lingkup sekolah.

Sekolah sebagai suatu lembaga pendidikan merupakan small community, suatu masyarakat dalam skala kecil, sehingga gagasan untuk mewujudkan masyarakat 


\section{Tusiyari}

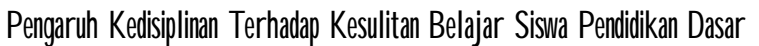

madani perlu diwujudkan dalam tata kehidupan sekolah. Salah satu upaya yang dapat dilakukan saat ini adalah perlu menyusun perangkat tata kehidupan sosial sekolah yang merupakan acuan norma yang harus dibuat dan dilaksanakan oleh setiap sekolah. Acuan ini bukan hanya mencakup tata tertib sekolah sebagaimana yang berlaku seperti sekarang ini, tetapi meliputi semua aspek tata kehidupan sosial sekolah yang mengatur tata hubungan antara siswa-siswi, siswa-guru, guru-guru, kepala sekolah-siswa/guru/pegawai sekolah. Warga sekolah-masyarakat.

Mengingat pentingnya pendidikan itu bagi kehidupan, maka pendidikan harus dilaksanakan sebaik-baiknya sehingga dapat memperoleh hasil yang di harapkan, sekolah sebagai lembaga pendidikan formal merupakan tempat yang paling memungkinkan seseorang meningkatkan pengetahuan, dan paling mudah membina generasi muda yang dilaksanakan oleh pemerintah dan masyarakat. Belajar dengan disiplin yang terarah dapat menghindarkan diri dari rasa malas dan menimbulkan kegairahan siswa dalam belajar, yang pada akhirnya akan dapat meningkatkan daya kemampuan belajar siswa.

Sekolah dan madrasah memiliki tanggung jawab yang besar untuk membantu siswa agar berhasil dalam belajar juga dalam menciptakan sebuah kedisiplinan dalam diri siswa tersebut, untuk itu sekolah dan madrasah hendaknya memberikan bantuan kepada siswa untuk mengatasi masalah-masalah yang timbul dalam kegiatan belajar siswa yaitu di dalam kesulitan belajar yang peserta didiknya tidak dapat belajar sebagaimana mestinya.

Kesulitan belajar pada anak atau sering disebut dengan learning disorders sangat erat kaitannya dengan pencapaian hasil akademik dan juga aktivitas seharihari. Dalam kurikulum pendidikan dijelaskan bahwa kesulitan belajar merupakan terjemahan dari bahasa inggris "Learning Disability" yang berarti ketidakmampuan belajar. Kata disability diterjemahkan "kesulitan" untuk memberikan kesan optimis bahwa anak sebenarnya masih mampu untuk belajar .

Anak yang mengalami kesulitan belajar adalah yang memiliki gangguan satu atau lebih dari proses dasar yang mencakup pemahamn penggunaan bahasa lisan atau tulisan, gangguan tersebut mungkin menampakkan diri dalam bentuk kemampuan yang tidak sempurna dalam mendengarkan, berpikir, berbicara, membaca, menulis, mengeja, atau menghitung. Selain itu, kesulitan belajar merupakan suatu kondisi dimana kompetensi atau prestasi yang dicapai tidak sesuai dengan kriteria standar yang telah ditetapkan, baik berbentuk sikap, pengetahuan maupun keterampilan. Proses belajar yang ditandai dengan adanya hambatan-hambatan tertentu untuk menggapai hasil belajar.

Oleh karena itulah anak yang mengalami kesulitan belajar, akan sukar dalam menyerap materi-materi pelajaran yang disampaikan oleh guru sehingga ia akan malas 


\section{Tusiyari}

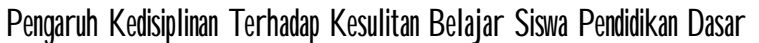

dalam belajar. Selain itu anak tidak dapat menguasai materi, bahkan menghindari pelajaran, mengabaikan tugas-tugas yang diberikan guru, sehingga terjadi penurunan nilai belajar dan prestasi belajar menjadi rendah.

Sebagaimana uraian diatas, peneliti mengamati bahwa apabila tata tertib atau peraturan akan dijalankan dengan baik oleh semua unsur pendidikan (guru, murid, kepala sekolah, pegawai dan lain-lain) maka akan dapat memberikan pengaruh positif pada prestasi belajar siswa.

Upaya peningkatan disiplin belajar dan kesulitan belajar dapat dilakukan oleh pihak sekolah maupun oleh pihak orang tua siswa. Salah satu cara yang dapat dilakukan oleh pihak sekolah untuk meningkatkan disiplin belajar dan kesulitan belajar siswa yaitu melalui kegiatan pembinaan siswa dengan memberikan layanan bimbingan belajar kepada siswa dan memberikan tambahan pelajaran yang dapat dilaksanakan setelah jam pelajaran sekolah selesai, sedangkan orang tua dapat melakukan pengawasan terhadap kegiatan belajar siswa. Disamping itu para pendidik dan orang tua dapat melakukan pembinaan dengan jalan memberikan contoh teladan yang berupa sikap dan perbuatan yang baik.

Berdasar latar belakang di atas, maka peneliti dalam penelitian ini memilih judul "Pengaruh Kedisiplinan Terhadap Kesulitan Belajar Siswa Kelas V SDN Kalimook I Kabupaten Sumenep"

\section{METODE PENELITIAN}

Teknik penelitian yang di gunakan oleh peneliti adalah teknik Penelitian ex post facto menguji apa yang telah terjadi pada subjek. Ex post facto secara harfiah berarti "sesudah fakta", karena kausa atau sebab yang diselidiki tersebut sudah berpengaruh terhadap variabel lain. Penelitian ini disebut penelitian kausal komparatif karena dimaksud untuk menyelidiki kausa yang mungkin untuk suatu pola prilaku yang dilakukan dengan cara membandingkan subjek dimana pola tersebut ada dengan subjek yang serupa dimana pola tersebut tidak ada atau berbeda (Glass \& Hopkin, 1979). Tujuan utama penelitian ini adalah untuk menyelidiki apakah satu atau lebih kondisi yang sudah terjadi mungkin menyebabkan perbedaan perilaku pada subjek. Dengan kata lain, penelitian ini untuk menentukan apakah perbedaan yang terjadi antar kelompok subjek (dalam variabel independen) menyebabkan terjadinya perbedaan pada variabel dependen.

Desain yang digunakan adalah desain penelitian kasus kontrol yang di mana peneliti melakukan pengukuran pada variabel terikat terlebih dahulu. Sedangkan variabel bebas diteliti secara retrospektif untuk menentukan ada tidaknya pengaruh pada variabel terikat. 


\section{Tusiyari}

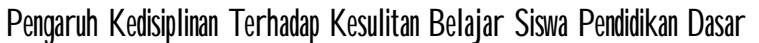

Penelitian diadakan dengan suatu tujuan tertentu yaitu menjawab pertanyaan-pertanyaan yang timbul dalam suatu penelitian untuk mengungkapkan suatu fenomena tertentu atau untuk mengambil kesimpulan hasil penelitian. Setelah merumuskan hipotesis, mengumpulkan data, memproses data kemudian membuat analisis data. Setelah semua itu terkumpul selanjutnya menganalisis data tersebut guna mengetahui hasilnya. Mengingat data yang terkumpul berupa angka-angka maka teknik yang tepat adalah menggunakan statistik.

Teknik statistik digunakan dalam penelitian ini dengan menggunakan berbagai pertimbangan : (1). Data yang telah terkumpul dari angket selanjutnya dinilai dengan angka, maka data yang didapat berwujud angka atau data kuantitatif, (2). Peneliti ingin melihat hasil penelitian sesubyektif mungkin, (3). Dengan menggunakan teknik statistik penganalisaannya lebih teliti, sehingga hasilnya lebih bagus.

Data yang diperoleh dari suatu penelitian tidak dapat dipergunakan begitu saja. Agar data yang diperoleh memberikan suatu keterangan yang dapat dipahami, tepat dan teliti maka dibutuhkan suatu pengolahan lebuh lanjut pada data tersebut. Sesuai dengan sifat data yang diperoleh, yaitu data yang bersifat kuantitatif, maka dipergunakan metode analisis statistik.

Setelah memberikan skor, kegiatan selanjutnya adalah memasukkan data yang diperoleh (berupa skor) ke dalam tabel dan mengelompokkan menjadi seperangkat data. Pengelompokan data ini berdasarkan hasil kuesioner atau angket. Adapun rumus yang digunakan adalah korelasi product moment.

$$
\mathrm{rxy}=\frac{N \sum x y-\left(\sum x\right)\left(\sum y\right)}{\left.\sqrt{\left(N \sum x^{2}\right.}-\left(\sum x\right)^{2}\right)\left(N \sum y^{2}-\left(\sum y\right)^{2}\right)}
$$

Dengan ketentuan sebagai berikut :

$\mathrm{X}$ : Adalah kedisiplinan

$\mathrm{Y}$ : Adalah data kesulitan belajar siswa

Rxy : Adalah angka indeks korelasi "r" product moment

$\sum x y$ : Jumlah hasil perkalian antara $\mathrm{X}$ dan $\mathrm{Y}$

$\sum \mathrm{x}$ : Jumlah seluruh skor $\mathrm{X}$

$\sum \mathrm{y}:$ Jumlah seluruh skor $\mathrm{Y}$

$\mathrm{N}$ : Number of Cases

2. Norma Keputusan

Norma keputusan digunakan untuk mempermudah penulis mendeskripsikan data dengan menggunakan analisis persentase. Rentangan persentase mengikuti Sutrisno Hadi,(1971) yaitu: Memberikan Interpretasi terhadap angka indeks korelasi " $r$ " product moment: 1 Interpretasi kasar atau sederhana, yaitu dengan mencocokkan 


\section{Tusiyari}

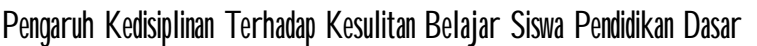

perhitungan dengan angka indeks korelasi "r" product moment. Interpretasi menggunakan tabel nilai "r" product moment (rt), dengan terlebih dahulu mencari derajat besarnya $(\mathrm{db})$ atau degress of freedom (df) yang rumusnya adalah :

$$
\text { df }=\mathbf{N}-\mathbf{n r}
$$

df : Degrees of Freedom

$\mathrm{N}$ : Number of Cases

$\mathrm{Nr}$ : Banyaknya variabel (Kedisiplinan belajar dan Kesulitan belajar)

Kemudian dengan melihat Tabel nilai Koefisisen Korelasi "r" Product Moment dari Pearson untuk Berbagai (df).

Dengan memperoleh db atau df maka dapat dicari besarnya " $r$ " yang tercantum dalam Tabel Nilai "r" Produt Moment, baik pada taraf signifikan $5 \%$ maupun taraf 1 $\%$. Jika ro sama dengan atau lebih besar dari pada $r t$ maka hipotesa alternatif $\left(\mathrm{H}_{1}\right)$ disetujui atau diterima atau terbukti kebenarannya. Sebaliknya, jika Hipotesa Nihil (Ho) tidak dapat disetujui atau tidak dapat diterima atau tidak dapat terbukti kebenarannya.

\section{HASIL PENELITIAN DAN PEMBAHASAN}

Salah satu teknik pengumpulan data untuk variabel kedisiplinan adalah menggunakan angket yang disebarkan pada responden berdasarkan sampel. Dan skoring data variabel $\mathrm{X}$, kedisiplinan dapat dilihat di lampiran.

Data hasil penelitian yang di dapat dari kedisiplinan menunjukkan bahwa dapat diketahui kualifikasi dan interval nilai sebagai berikut:

\section{Tabel Kualifikasi dan Interval Nilai Kedisiplinan}

\begin{tabular}{|c|c|c|}
\hline No & Interval & Keterangan \\
\hline 1. & $41-49$ & Sangat Buruk \\
\hline 2. & $50-58$ & Buruk \\
\hline 3. & $59-67$ & Cukup \\
\hline 4. & $68-76$ & Sangat Cukup \\
\hline 5. & $77-85$ & Baik \\
\hline 6. & $86-94$ & Sangat Baik \\
\hline 7. & $95-103$ & Amat baik \\
\hline
\end{tabular}

Dari hasil diatas maka dapat diketahui bahwa hasil dari nilai kedisiplinan dibagi menjadi tujuh interval yang dimulai dari keterangan amat baik sampai sangat buruk. Dan dari hasil ini maka selanjutnya mencari distribusi frekuensi untuk 


\section{Tusiyari}

mencari hasil nilai yang diperoleh oleh siswa kelas VII SMP Negeri 1 Kalianget, maka diperoleh distribusi frekuensi sebagai berikut:

\section{Distribusi Frekuensi Kedisiplinan}

\begin{tabular}{|c|c|c|c|}
\hline No & Interval & Frekuensi & Fr (\%) \\
\hline 1. & $41-49$ & 2 & 3,57 \\
\hline 2. & $50-58$ & 5 & 8,93 \\
\hline 3. & $59-67$ & 8 & 14,29 \\
\hline 4. & $68-76$ & 4 & 7,14 \\
\hline 5. & $77-85$ & 5 & 8,93 \\
\hline 6. & $86-94$ & 14 & 25 \\
\hline 7. & $95-103$ & 18 & 32,14 \\
\hline \multicolumn{2}{|c|}{ Jumlah } & $\mathbf{5 6}$ & $\mathbf{1 0 0}$ \\
\hline
\end{tabular}

Dari tabel diatas dapat diketahui bahwa interval 41 - 49 dengan nilai 3,57\%, untuk interval 50 - 58 dengan nilai 8,93\%, untuk interval 59 - 67 dengan nilai $14,29 \%$, untuk interval 68 - 76 dengan nilai $7,14 \%$, untuk interval 77 - 85 dengan nilai 8,93\%, untuk interval 86 - 94 dengan nilai 25\%, dan untuk interval 95 - 103 dengan nilai $32,14 \%$.

Dari analisa mencari nilai Mean maka sudah dapat diketahui bahwa kedisiplinan siswa kelas VII SMP Negeri 1 Kalianget termasuk kategori amat baik yaitu berada pada interval 95 - 103 dengan nilai rata-rata 81,82 dan frekuensi relatifnya $32,14 \%$.

Data hasil penelitian yang di dapat dari kesulitan belajar siswa menunjukkan bahwa dapat diketahui kualifikasi dan internal nilai sebagai berikut:

\section{Kualifikasi dan Interval Nilai Kesulitan Belajar Siswa}

\begin{tabular}{|c|c|c|}
\hline No & Interval & Keterangan \\
\hline 1. & $43-50$ & Sangat Buruk \\
\hline 2. & $51-58$ & Buruk \\
\hline 3. & $59-66$ & Cukup \\
\hline 4. & $67-74$ & Sangat Cukup \\
\hline 5. & $75-82$ & Baik \\
\hline
\end{tabular}




\section{Tusiyari}

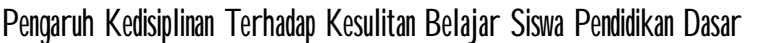

\begin{tabular}{|c|c|c|}
\hline 6. & $83-90$ & Sangat Baik \\
\hline 7. & $91-98$ & Amat baik \\
\hline
\end{tabular}

Dari hasil diatas maka dapat diketahui bahwa hasil dari nilai kesulitan belajar siswa dibagi menjadi tujuh interval yang dimulai dari keterangan amat baik sampai sangat buruk. Dari hasil ini maka selanjutnya mencari distribusi frekuensi untuk mencari hasil nilai yang diperoleh siswa kelas VII SMP Negeri 1 Kalianget, maka diperoleh distribusi frekuensi sebagai berikut:

\section{Distribusi Frekuensi Kesulitan Belajar Siswa}

\begin{tabular}{|c|c|c|c|}
\hline No & Interval & Frekuensi & Fr (\%) \\
\hline 1. & $43-50$ & 2 & 3,57 \\
\hline 2. & $51-58$ & 7 & 12,5 \\
\hline 3. & $59-66$ & 5 & 8,93 \\
\hline 4. & $67-74$ & 12 & 21,43 \\
\hline 5. & $75-82$ & 14 & 25 \\
\hline 6. & $83-90$ & 7 & 12,5 \\
\hline 7. & $91-98$ & 9 & 16,07 \\
\hline \multicolumn{2}{|c|}{ Jumlah } & $\mathbf{5 6}$ & $\mathbf{1 0 0}$ \\
\hline
\end{tabular}

Dari tabel diatas dapat diketahui bahwa interval 43 - 50 dengan nilai 3,57\%, untuk interval 51 - 58 dengan nilai 12,5\%, untuk interval 59 - 66 dengan nilai 8,93\%, untuk interval 67 - 74 dengan nilai 21,43\% dan untuk interval 75 - 82 dengan nilai $25 \%$, untuk interval 83 - 90 dengan nilai $12,5 \%$ dan untuk interval 91 - 98 dengan nilai $16,07 \%$.

Dari analisa mencari nilai Mean maka dapat diketahui bahwa kesulitan belajar siswa kelas VII SMP Negeri 1 Kalianget termasuk kategori baik yaitu berada pada interval 75 - 82 dengan nilai rata-rata 74,93 dan frekuensi relatifnya $25 \%$. 


\section{Tusiyari}

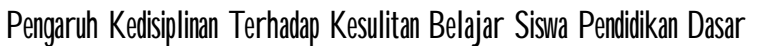

Selanjutnya untuk mengetahui adanya pengaruh kedisiplinan terhadap kesulitan belajar siswa kelas VII SMP Negeri 1 Kalianget, maka dilakukan tehnik analisa Product Moment sebagai berikut:

$$
\operatorname{rxy}=\frac{N \sum x y-\left(\sum x\right)\left(\sum y\right)}{\left.\sqrt{\left(N \sum x^{2}\right.}-\left(\sum x\right)^{2}\right)\left(N \sum y^{2}-\left(\sum y\right)^{2}\right)}
$$

Dengan ketentuan sebagai berikut :

$\mathrm{X}$ : Adalah kedisiplinan

Y : Adalah data kesulitan belajar siswa

Rxy : Adalah angka indeks korelasi "r" product moment

$\sum x y$ : Jumlah hasil perkalian antara $\mathrm{X}$ dan $\mathrm{Y}$

$\sum \mathrm{x}$ : Jumlah seluruh skor $\mathrm{X}$

$\sum y$ : Jumlah seluruh skor $\mathrm{Y}$

$\mathrm{N}$ : Number of Cases

Penyelesaian:

$$
\begin{aligned}
& \mathrm{r}_{\mathrm{xy}}=\frac{N \sum x y-\left(\sum x\right)\left(\sum y\right)}{\left.\sqrt{\left(N \sum x^{2}\right.}-\left(\sum x\right)^{2}\right)\left(N \sum y^{2}-\left(\sum y\right)^{2}\right)} \\
& \mathrm{r}_{\mathrm{xy}}=\frac{56 \times 352634-\left(\sum 4582\right)\left(\sum 4196\right)}{\left.\sqrt{(56 \times 392182}-(4582)^{2}\right)\left(56 x \sum 324254-(4196)^{2}\right)} \\
& \mathrm{r}_{\mathrm{xy}}=\frac{19747504-19226072}{\sqrt{(21962192}-20994724)(18158224-17606416} \\
& \mathrm{r}_{\mathrm{xy}}=\frac{521432}{\sqrt{967468 x} 551808} \\
& \mathrm{r}_{\mathrm{xy}}=\frac{521432}{\sqrt{533856582144}} \\
& \mathrm{r}_{\mathrm{xy}}=\frac{521432}{730654,899} \\
& \mathrm{r}_{\mathrm{xy}}=0,714
\end{aligned}
$$

1. Interpretasi Hasil Analisis Data

Berdasarkan hasil analisis diperoleh $r_{\text {hitung }}=0,714$ sedangkan $r_{\text {tabel }}=0,266$ (untuk $\mathrm{db}=56$ ), maka diputuskan $r_{\text {hitung }}=\geq r_{\text {tabel }}$ pada taraf signifikan 5\%,yang berarti hipotesis alternative diterima. Sehingga terbukti bahwa hipotesa nihil $\left(\mathrm{H}_{\mathrm{o}}\right)$ yang berbunyi "Tidak ada pengaruh kedisiplinan terhadap kesulitan belajar siswa" 


\section{Tusiyari}

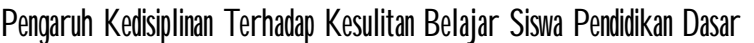

ditolak, sedangkan hipotesa kerja $\left(\mathrm{H}_{\mathrm{a}}\right)$ yang berbunyi "Ada pengaruh kedisiplinan terhadap kesulitan belajar siswa" diterima.

C. Pembahasan

1. Hipotesis pertama

Hipotesis alternatif diterima jika $: \boldsymbol{r}_{\text {hitung }} \geq \boldsymbol{r}_{\text {tabel }}$ yaitu $0,989 \geq 0,266$ berarti masuk pada daerah kritik maka ada pengaruh yang signifikan antara kedisiplinan terhadap kesulitan belajar siswa kelas VII SMP Negeri 1 Kalianget Tahun Ajaran 20112012.

2. Hipotesis kedua

Hipotesis alternatif diterima jika $: \boldsymbol{r}_{\text {hitung }} \leq \boldsymbol{r}_{\text {tabel }}$ yaitu $0,989 \leq 0,266$ berarti tidak masuk pada daerah kritik maka tidak ada pengaruh yang signifikan antara kedisiplinan terhadap kesulitanbelajar siswa kelas VII SMP Negeri 1 Kalianget Tahun Ajaran 2011- 2012.

\section{KESIMPULAN}

Berdasarkan rumusan masalah dan tujuan penelitian, dapat diambil kesimpulan sebagai berikut:

1. Tingkat kedisiplinan siswa kelas VII SMP Negeri 1 Kalianget masuk dalam kategori amat baik karena mean atau rata-rata tingkat kedisiplinan adalah 81,82 yang berada pada interval 95 - 103 dengan nilai 32,14\%, maka dari sini tingkat kedisiplinan siswa kelas VII amat baik karena masuk dalam tingkat nilai yang amat baik.

2. Tingkat kesulitan belajar siswa kelas VII SMP Negeri 1 Kalianget masuk dalam kategori baik karena mean atau rata-rata tingkat kesulitan belajar siswa adalah 74,93 berada pada interval 75 - 82 dengan nilai $25 \%$ maka dari sini tingkat kesulitan belajar siswa kelas VII baik karena masuk dalam tingkat nilai yang baik.

3. Berdasarkan hasil analisis data dan uji hipotesis diperoleh data $\mathbf{r}_{\text {hitung }}$ adalah 0,714 dan $r_{\text {tabel }}$ adalah 0,266 pada taraf kepercayaan 95\% ,maka Ha diterima dan Ho ditolak. Hal tersebut menunjukkan bahwa ada pengaruh kedisiplinan terhadap kesulitan belajar siswa kelas VII SMP Negeri 1 Kalianget Tahun Ajaran 2011/2012. Sekaligus sesuai dengan landasan teori yang digunakan pada penelitian ini.

Berdasarkan hasil penelitian yang telah dilakukan, implikasi yang dapat diberikan adalah untuk membantu memberikan informasi khususnya kepada para orang tua, konselor sekolah dan guru dalam upaya membimbing dan memotivasi siswa untuk mengetahui bagaimana meningkatkan kedisiplinan supaya dapat meminimalisis kesulitan dalam belajar. Di dalam meningkatkan kedisiplinan maka siswa akan menjadi orang sukses dan motivasi belajarnya akan tinggi. Hal ini akan berdampak baik untuk kemajuan prestasi belajar siswa. 


\section{Tusiyari}

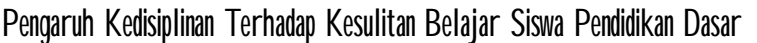

\section{DAFTAR PUSTAKA}

Abdurrahman, Mulyono. 2003. Pendidikan bagi Anak Berkesulitan Belajar. Jakarta: Rineka Cipta

Jaali, H.2007.Psikologi Pendidikan.jakarta:Bumi Aksara

Ki Fudyartanta,2010.Membangun Kepribadian dan Watak Bangsa Indonesia Yang harmonis dan Integral.Yogyakarta:Pustaka Pelajar

Margono, S. 2007. Metodologi Penelitian Pendidikan. Jakarta: Rineka Cipta

Musaheri,2006. Perkembangan Peserta Didik untuk memiliki kompetensi pedagogik.Yogyakarta:Pustaka Pelajar

Mustaqim, Abdul Wahib. 1991. Psikologi Pendidikan. Jakarta: Rineka Cipta.

Nazir, Moh. 2003. Metode Penelitian. Jakarta: Ghalia Indonesia.

Nini Subini,2011.Mengatasi Kesulitan Belajar pada Anak. Jogjakarta:Javalitera

Priyatno, Erman Anti. 1999. Dasar-dasar Bimbingan dan Konseling. Jakarta: Rineka Cipta.

Purwanto, Ngalim. 1990. Psikologi Pendidikan. Bandung: PT. Remaja Rosdakarya.

Purwanto, Ngalim. 1998. Psikologi Pendidikan, Bandung : PT. Remaja Rosda Karya.

Riyanto, Theo. 2002. Pembelajaran Sebagai Suatu Bimbingan Pribadi. Jakarta.: Grasindo.

Suharsini, Arikunto. 2006. Prosedur Penelitian Suatu Pendekatan Praktek. Jakarta: Rineka Cipta.

Sancaya, Satya, Adi. 2010. Metode Penelitian dan Penulisan Skripsi. Kediri: Universitas Nusantara PGRI Kediri.

Sutrisno, Tri. 2013. Komunikasi Konseling. Jakarta Barat: Halaman Moeka Publishing.

Sutrisno, Tri. 2014. Asupan Psikologis Anak Melalui Konseling. Jakarta Barat: Halaman Moeka Publishing

Usman, Husaini dan Akbar, Purnomo, Setiady. 2006. Pengantar Statistika Edisi Kedua. Jakarta: Bumi Aksara. 